\title{
Variation in ion accumulation as a measure of salt tolerance in seedling and callus of Stylosanthes guianensis
}

\section{Varaporn Veraplakorn ${ }^{1,2}$, Malee Nanakorn ${ }^{2 *}$, Lily Kaveeta ${ }^{2}$, Srisom Suwanwong ${ }^{2}$, Ian James Bennett ${ }^{3}$}

'Department of Biotechnology, Faculty of Science, Ramkhamhaeng University, Bangkok, Thailand.

${ }^{2}$ Department of Botany, Faculty of Science, Kasetsart University, Bangkok, Thailand.

${ }^{3}$ School of Natural Sciences, Edith Cowan University, Western Australia.

*Corresponding author : fscimln@ku.ac.th

Received: 19 December 2012; Accepted: 10 July 2013

ABSTRACT: Seedlings of Stylosanthes guianensis CIAT 184 (Stylo 184) were germinated under salt-stress conditions (0-170.9 mM NaCl), and germination and ion content $\left(\mathrm{Cl}^{-}, \mathrm{Na}^{+}, \mathrm{Ca}^{2+}, \mathrm{Mg}^{2+}\right.$ and $\left.\mathrm{K}^{+}\right)$were measured after seven days. The salt treatment had no effect on the germination percentage, but the seedling showed reduced growth and displayed variation in ion uptake, thus accumulating $\mathrm{Na}^{+}$and $\mathrm{Cl}^{-}$in the roots. Callus produced from seedlings selected as salt sensitive ( $T 1$ ) or salt tolerant ( $T 2, T 3, T 4$ and $T 5$ ) was examined for growth and ion content under the influence of $\mathrm{NaCl}$ (0-256.4 mM NaCl) after 15 days. The sensitive clone ( $\mathrm{T} 1)$ contained the lowest $\mathrm{Na}^{+}$and $\mathrm{Cl}^{-}$content with the highest percentage of $\mathrm{K}^{+}$contributing to osmolality, suggesting it possesses an ion regulation mechanism that is typical of glycophytes; i.e., osmotic potential was adjusted by accumulating $\mathrm{K}^{+}$. The other clones (T2, T3, T4 and T5) expressed different strategies (osmotic adjustment) to cope with salt stress. T5 showed the highest mean dry weight on salt medium and displayed more effective ion regulation by maintaining low $\mathrm{Na}^{+}: \mathrm{K}^{+}$and $\mathrm{Na}^{+}: \mathrm{Ca}^{2+}$ ratios. T2 expressed high $\mathrm{Na}^{+}$and $\mathrm{Cl}^{-}$with the highest percentage of $\mathrm{Na}^{+}$contribution to osmolality and water content (succulence). T3 and T4 had lower growth rates but similar ion regulation in relation to T5. Results indicated that the ion content can be used to discriminate salt sensitive and salt tolerant clones of Stylo 184.

KEYWORDS: forage legume, ion exclusion, osmolality, osmotic adjustment.

\section{INTRODUCTION}

Soil salinisation is one of the most essential problems in agricultural production throughout the world (Munns 2002, Flowers 2004). Approaches to overcoming this problem have been both physical and biological. Physical approaches generally concentrate on controlling water regimes, and hence the transportation of salts in irrigation and in soil profiles (Mostafazadeh-Fard et al. 2007). Biological approaches concentrate on the mechanisms that lead to salt tolerance and on the subsequent selection of these characteristics in a variety of plants. Munns (2002) suggested several approaches to recognize salt tolerance in crop plants, including the regulation of ion uptake. Examining these physiological aspects of salt tolerance has led to a range of promising results for the increased production under saline conditions. The production of salt-tolerant crops, however, does not necessarily address the cause of the problem, and without improved irrigation methods and alleviation of soil salinisation caused in dryland salinity (by the alteration of groundwater levels), the problem will be aggravated. 
Legumes are a prime example of plants that have several functions because they contribute with soil nitrogen content and provide products such as crops or fodder. This refers especially to deep rooted perennials, as they are able to alleviate problems with rising water tables. The use of legumes to address saline soil problems has been widely recommended, however, legumes are generally sensitive to salt, and this fact has limited their application (Betteridge and Jones 2001, Ashraf and Iram 2005, Al Sherif 2009, Saha et al. 2010).

Legumes are generally classified as glycophytes. Salttolerant glycophytes are able to deal with salt stress by relying on a range of mechanisms including osmotic adjustment, specific ion exclusion/transport, compartmentalization, or a combination of them (Munns 2002, Tejera et al. 2006, Zakharin and Panichkin 2009). Within the glycophytes, however, different species display a range in salt tolerance. With legumes, ion exclusion has been identified as a major tolerance mechanism (Luo et al. 2005). Nevertheless, overproduction and accumulation of organic osmolytes (i.e., proline and reducing sugars) have also been reported (Sidari et al. 2008, Arulbalachandran et al. 2009, Amirjani 2010). Some legumes, such as chickpea, are able to accumulate $\mathrm{Na}^{+}$and $\mathrm{K}^{+}$in their roots, which decrease the root osmotic potential (Tejara et al. 2006). Other salt-tolerant glycophytes such as Aster tripolium (Ueda et al. 2003) and Trachyspermum ammi have also shown osmotic adjustment with the accumulation of $\mathrm{Na}^{+}$and $\mathrm{Cl}^{-}$ (Ashraf and Orooj 2006).

It appears that $\mathrm{K}^{+}$uptake under salt stress may be particularly important in-salt tolerant glycophytes. It is essential to maintain the cytoplasmic reactions and it is presumed to be acting as a nonorganic solute, as the levels of accumulation are insufficient to lead to osmotic adjustment (Yokoi et al. 2002). Also, $\mathrm{K}^{+}$and $\mathrm{Mg}^{2+}$ have been reported to play an important role in enzyme activation (Barker and Pilbeam 2007). The role of $\mathrm{Mg}^{2+}$ is unclear under salt stress, since responses have been variable in vitro. For instance, it increases in rice callus (Ahmad et al. 2009), decreases in soybean callus (Liu and Staden 2001), and is unaffected in callus of Sonneratia alba J. Smith (Yasumoto et al. 1999).

Stylosanthes species are important forage legumes that originate from the tropical Americas. S. guianensis CIAT 184 (Stylo 184) is widely grown in sub-tropical and tropical regions including the Philippines, Australia, Indonesia, Malaysia, Vietnam, Laos, and Thailand. It has exceptional forage value and high protein content (approximately 14-18\% foliage) and is well adapted to a range of soil types from sand to light clay, but is sensitive to saline and sodic soils $(\mathrm{pH}>8.5)$ (Phengsavanh and Ledin 2003, Homma et al. 2008).

Some of the best investigations of the traits in relation to salt tolerance are those associated with the ion contents of plants grown under saline conditions (Flowers 2004) and in the past decade, in vitro selection for salt tolerant lines has been reported as being sucssessful (Hassan et al. 2004, Woodward and Bennett 2005, Bekheet et al. 2006, Kashyap and Sharma 2006). In this study, we hypothesized that ion regulation in plant tissue contributes to salt tolerance in Stylo 184, and we aimed to determine whether ion regulation in seedlings or callus could be used to select salt tolerant individuals.

\section{MATERIAL AND METHODS}

Germination and growth: Seeds of Stylo 184 were obtained from the Animal Nutrition Division, Department of Livestock, Thailand. Seeds were soaked in warm water at $80^{\circ} \mathrm{C}$ for $1-2 \mathrm{~min}$ in order to break dormancy and then were immersed in $1 \%$ $\mathrm{NaOCl}$ for 30 min followed by five rinses in sterile distilled water. Surface-sterilized seeds were placed in Petri dishes (20 seeds per dish) and exposed to $2 \mathrm{~mL}$ of $0,85.5,128.2$ and 170.9 $\mathrm{mM} \mathrm{NaCl}$ for seven days. A completely randomized design (CRD) was used with five replicates. Germination percentage, shoot height, root length, and ion content $\left(\mathrm{Ca}^{2+}, \mathrm{Mg}^{2+}, \mathrm{Na}^{+}\right.$and $\mathrm{K}^{+}$) in shoots and roots were determined after the treatments (see details below).

\section{Growth and ion content in callus under salt stress:}

Based on our preliminary work and following salt-tolerant selection in potatoes (Jefferies 1996) and tomatoes (Foolad 1996), seeds of Stylo 184 were treated with $0-512.8 \mathrm{mM} \mathrm{NaCl}$. It was found that the $341.9 \mathrm{mM} \mathrm{NaCl}$ concentration was the highest at which seeds were able to germinate. In addition, germination was not significantly different from 0 to $170.9 \mathrm{mM}$. Salt-tolerant clones were therefore selected by germinating $60 \mathrm{~g}$ (approximately 37,500 of the sampling seeds from the same seed lot as the aforementioned one) in a sterile $341.9 \mathrm{mM} \mathrm{NaCl}$ solution. Every $100 \mathrm{mg}$ surface-sterilised seeds were germinated in a Petri dish containing a $10 \mathrm{~mL} \mathrm{NaCl}$ solution. Each germinated seed was evaluated for its salt tolerance (T2-T5). One sensitive clone (T1) was derived from a seed which did not germinate with $170.9 \mathrm{mM} \mathrm{NaCl}$, but germination was observed when salt stress was removed.

All of the five selected clones of stylo 184 (T1, T2, T3, T4 and T5) were then induced to form callus for four weeks by culturing on MS medium (Murashige and Skoog 1962), supplemented with $0.01 \mathrm{mg} \mathrm{L}^{-1}$ 6-alpha-naphthaleneacetic acid (NAA) and $1 \mathrm{mg} \mathrm{L}^{-1}$ benzyladenine (BA) at $25^{\circ} \mathrm{C}$ under a 16 -hour photoperiod (Veraplakorn et al. 2012). The callus of all clones was then proliferated on the same medium by subculture twice 
every four weeks. Their salt-tolerant capacity was examined by exposing the callus to the same medium, but with $0,85.5,170.9$ and $256.4 \mathrm{mM} \mathrm{NaCl}$. The experiment was set up using a factorial $\mathrm{CRD}$ and the relative growth rate $(\mathrm{RGR}=100 \times$ final dry weight stress/final dry weight control) (Yacoubi et al. 2010), and ion content was determined after 15 days.

Nutrient analysis and osmolality: At the end of the experiment, the seedlings and callus were dried up at $50^{\circ} \mathrm{C}$ for two days in a hot air oven. Samples were taken and ground into fine powder and $0.1 \mathrm{~g}$ ground samples were digested in $10 \mathrm{~mL}$ of $\mathrm{HNO}_{3}: \mathrm{HClO}_{4}$ acid mixture $(2: 1, \mathrm{v} / \mathrm{v})$ and kept at room temperature for one day. Samples were then heated at $100-150^{\circ} \mathrm{C}$ until being fully digested. Deionized water was added to adjust the final volume of $50 \mathrm{~mL}$ and filtered with a $0.2 \mu \mathrm{m}$ membrane filter (Ruiz et al. 1997). These samples were then analysed as to $\mathrm{Ca}^{2+}, \mathrm{Mg}^{2+}, \mathrm{Na}^{+}$and $\mathrm{K}^{+}$content using atomic absorption and flame emission spectrophotometer (Perkin Elmer, USA).

$\mathrm{Cl}^{-}$was determined by grinding $0.1 \mathrm{~g}$ of each sample, mixing with $0.1 \mathrm{~g} \mathrm{CaO}$ and $1 \mathrm{~mL}$ deionized water, and then combusting at $500^{\circ} \mathrm{C}$ for $3 \mathrm{~h}$. The ash was dissolved with $50 \mathrm{~mL}$ deionized water, and afterwards a $0.5 \mathrm{~mL}$ subsample was removed and mixed with $4.5 \mathrm{~mL}$ deionized water. The solution was added to $0.5 \mathrm{~mL}$ mercury thiocyanate $(0.075 \%)$ and $1.0 \mathrm{~mL}$ ferric nitrate nonahydrate $(4.04 \%)$. $\mathrm{Cl}^{-}$content was measured from the colour of the ferric thiocyanate complex with absorbance at $460 \mathrm{~nm}$ and compared with a standard $\mathrm{Cl}^{-}$curve (Adriano and Doner 1982).

For osmolality analysis of the cell sap, fresh callus was frozen at $-80^{\circ} \mathrm{C}$. After thawing, the callus was placed into a $1 \mathrm{~mL}$ syringe and the syringe plunger was pressed to express cell sap. Molality was determined by a Wescor model 5100C vapour pressure osmometer (New Jersey, USA). This sap osmolality value was multiplied by -2.48 to reach osmotic potential. The molal concentrations of $\mathrm{Na}^{+}$and $\mathrm{K}^{+}$were converted to osmolality by multiplying by 1.84 (Bell and O'Leary 2003).
Statistical analysis: A completely randomized design (CRD) was performed for germination percentage. The factorial experiment under CRD was carried out for other parameters, depending on whether the experiment involved seedlings ( $\mathrm{NaCl}$ concentrations and organs) or clones ( $\mathrm{NaCl}$ concentrations and clones). Equal variances were tested with Levene's test. When significant differences were found due to treatment, Tukey's B multiple range test was applied. Differences were considered significant when $\mathrm{p} \leq 0.05$. All analyses were performed using the software PASW Statistics 18.

\section{RESULTS}

\section{Germination, growth and ion content in seedling:} The control group germinated in sterilized water illustrated normal growth with the highest shoot and root lengths. Salt treatments of 0 to $170.9 \mathrm{mM} \mathrm{NaCl}$ had no significant effects on germination percentage (Figure 1A). However, $\mathrm{NaCl}$ reduced seedling growth. Shoot and root lengths of seedlings germinated in $85.5 \mathrm{mM} \mathrm{NaCl}$ were significantly lower than those of the control group, while seeds exposed to $128.2 \mathrm{mM}$ and $170.9 \mathrm{mM} \mathrm{NaCl}$ showed even greater reduction, but no significant differences from one other (Figure 1B).

There was significant variation among salt treatments in both shoots and roots for $\mathrm{Na}^{+}$, and $\mathrm{Cl}^{-}$(Figure 2). As $\mathrm{NaCl}$ increased, the mean $\mathrm{Na}^{+}$and $\mathrm{Cl}^{-}$contents increased significantly, while $\mathrm{K}^{+}, \mathrm{Mg}^{2+}$ and $\mathrm{Ca}^{2+}$ contents remained constant. In addition, $\mathrm{Na}^{+}, \mathrm{Cl}-\mathrm{K}^{+}$and $\mathrm{Mg}^{2+}$ concentrations were higher in roots than in shoots (Figure 2). $\mathrm{Na}^{+}: \mathrm{K}^{+}$ratios increased significantly at $85.5 \mathrm{mM} \mathrm{NaCl}$ for both shoots and roots (Figure 3A). The $\mathrm{Na}^{+}: \mathrm{Ca}^{2+}$ ratios, however, did not
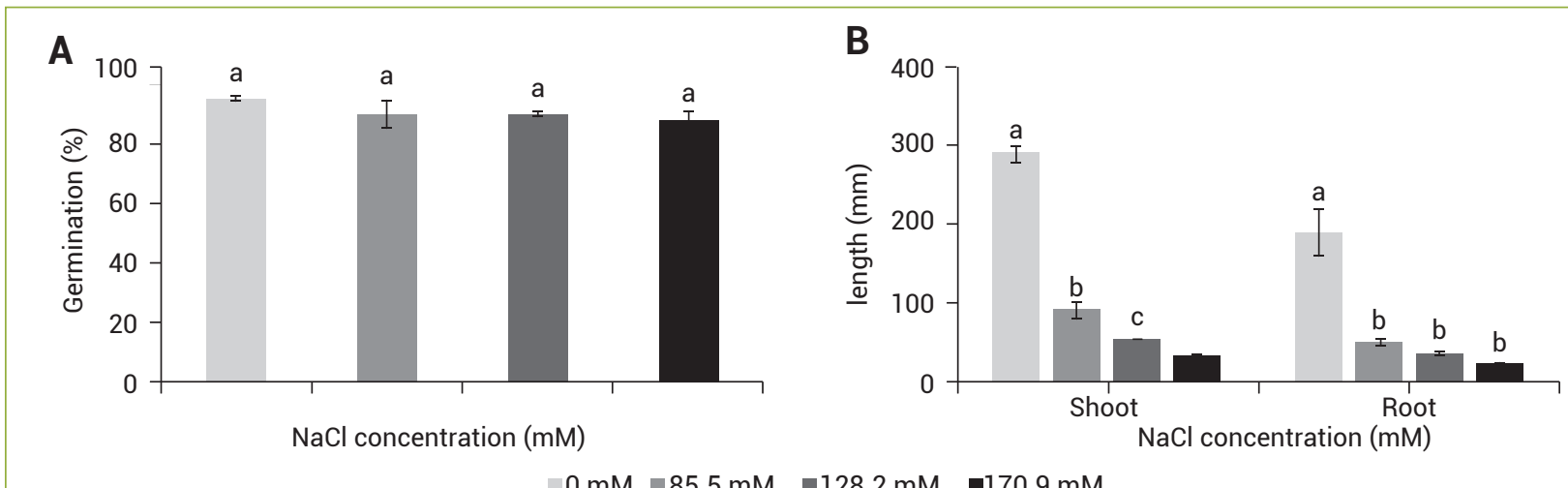

$0 \mathrm{mM} \quad \square 5.5 \mathrm{mM} \quad \square 128.2 \mathrm{mM} \quad \square 170.9 \mathrm{mM}$

Figure 1. Percent germination of stylo 184 seeds (A), and growth of 7-d-old seedlings (B) after treatment with $0-170.9 \mathrm{mM} \mathrm{NaCl}$. Error bars indicate standard error; $n=5$; different letters above bars indicate significant difference $(p \leq 0.05)$. 
change in shoots, but significantly increased in roots (Figure 3B). A reduction in water content was observed only in shoots at $170.9 \mathrm{mM} \mathrm{NaCl}$. In roots, however, water content was stable with increasing $\mathrm{NaCl}$ (Figure 4).

Growth and ion content in callus: For each of the measured parameters, the two-way ANOVA indicated there was a significant difference caused both by clone and treatment with the exception of $\mathrm{Mg}^{2+}$ content. In addition, there was a twoway interaction between the clones and treatment, indicating that not all clones responded the same way. The callus RGR of the five clones under the influence of $\mathrm{NaCl}(0-256.4 \mathrm{mM})$ varied both by clone and concentration with growth generally being reduced in increasing salt concentrations (Figure 5). Whereas T1, T2 and T4 showed reductions in RGR from $85.5 \mathrm{mM} \mathrm{NaCl}$, T3 displayed them only from $170.9 \mathrm{mM} \mathrm{NaCl}$. On the other hand, T5 only had significant reduction at 256.4 $\mathrm{mM} \mathrm{NaCl}$ (Figure 5).

Callus water content was also significantly reduced as $\mathrm{NaCl}$ concentration increased (Figure 6). However, while there were differences between clones, it did not reflect those seen in callus growth. T2 was able to maintain its water content at $85.5 \mathrm{mM} \mathrm{NaCl}$ with a significant reduction at $170.9 \mathrm{mM} \mathrm{NaCl}$ (compared to control), but there was no further reduction at $256.4 \mathrm{mM} \mathrm{NaCl}$. All the other clones had significant reduction in water content at the lowest $\mathrm{NaCl}$ concentration, of $85.5 \mathrm{mM}$.

The potential osmotic of all clones decreased significantly with the enhancement of $\mathrm{NaCl}$ concentration (Figure 7A). In addition, as $\mathrm{NaCl}$ increased, the contribution of $\mathrm{Na}^{+}$and $\mathrm{K}^{+}$ to osmolality varied among clones. The highest contribution of $\mathrm{Na}^{+}$was found in $\mathrm{T} 2$, while the lowest one was found in $\mathrm{T} 1$. In clones $\mathrm{T} 2, \mathrm{~T} 3$ and $\mathrm{T} 5$ there was an increasing contribution of $\mathrm{Na}^{+}$, but $\mathrm{T} 1$ and $\mathrm{T} 4$ remained stable from 85.5 to $256.4 \mathrm{mM} \mathrm{NaCl}$. Also, the contribution of $\mathrm{K}^{+}$to osmolality in T2, T3, T4 and T5 decreased significantly, but it was stable in all levels of $\mathrm{NaCl}$ for $\mathrm{T} 1$. $\mathrm{T} 1$ had the highest contribution of $\mathrm{K}^{+}$to osmolality (36.7\%) and $\mathrm{K}^{+}$was also the major contributor (59.3\%) in the medium without $\mathrm{NaCl}$ (Figure 7B).

The ion content of the callus depended on the clone and level of $\mathrm{NaCl}$ in the medium. $\mathrm{Na}^{+}$and $\mathrm{Cl}^{-}$were significantly higher for each clone with increasing $\mathrm{NaCl}$ application (Figures 8A, B). Based on the two-way ANOVA, T1 increased the least with growing $\mathrm{NaCl}$ and $\mathrm{T} 2$ increased the most for both $\mathrm{Na}^{+}$and $\mathrm{Cl}$. The other three clones had intermediate responses. For $\mathrm{K}^{+}$, there was a significant difference among the clones and the response to increasing $\mathrm{NaCl}$ varied again. In $\mathrm{T} 1$ and $\mathrm{T} 2$, there was no significant difference and also no change in $\mathrm{K}^{+}$over the four $\mathrm{NaCl}$ concentrations. However, the concentrations were twice as high in $\mathrm{T} 1$ compared to T3, T4 and T5 (Figure 8C). In addition, T5 was able to stabilize its $\mathrm{K}^{+}$
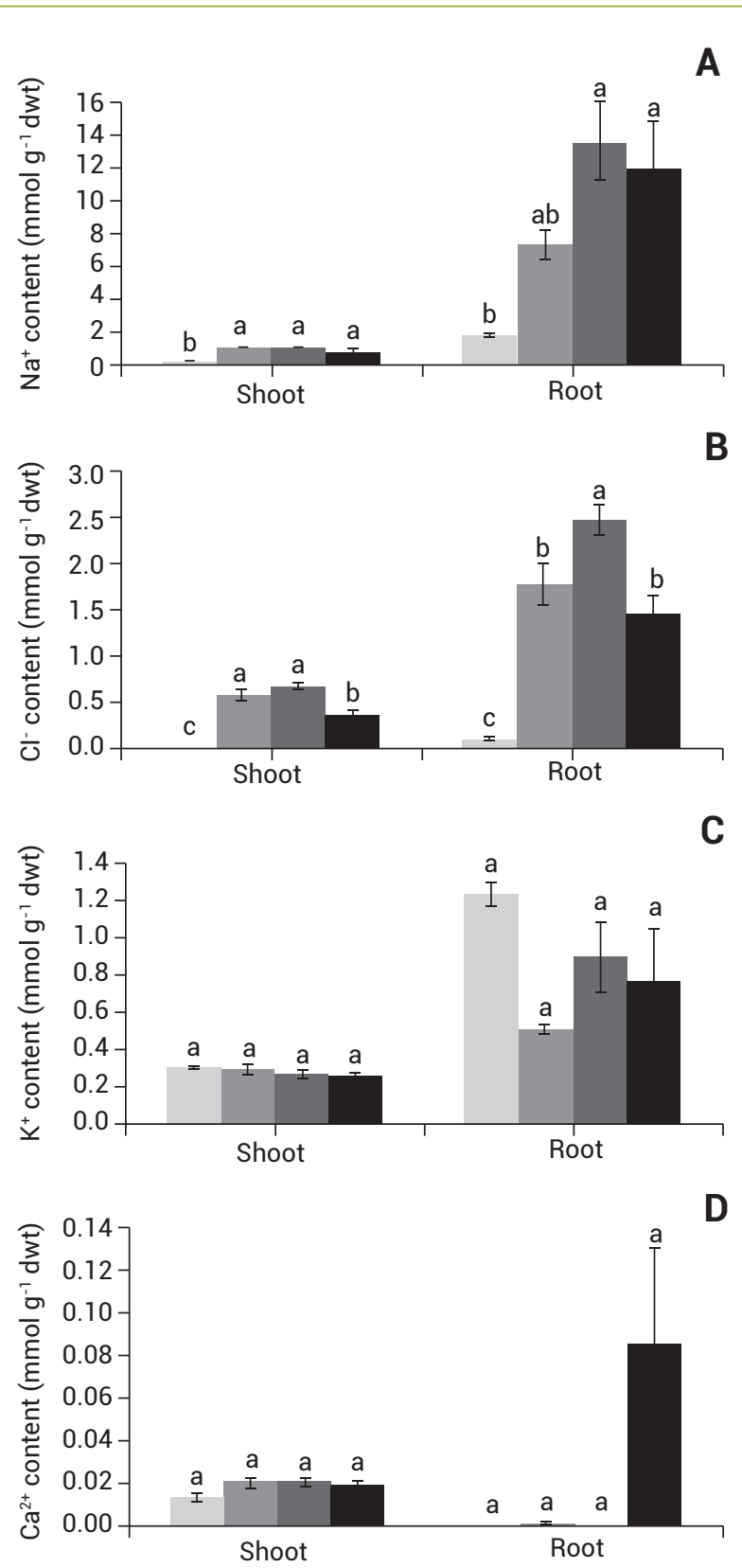

E

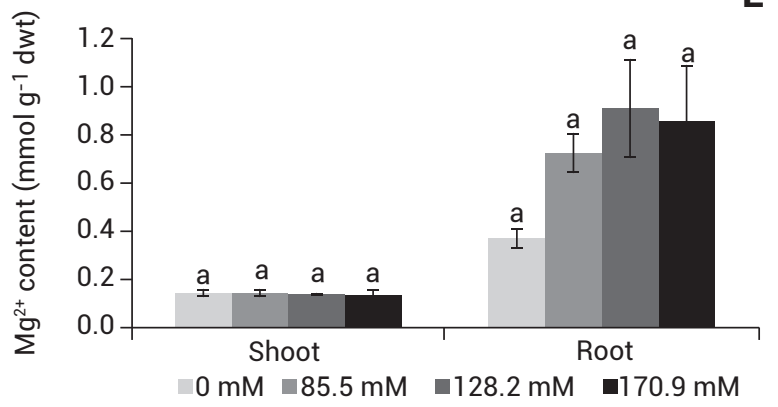

Figure 2. Ion content in 7-d-old seedlings of stylo 184 after treatment with 0-170.9 mM NaCl. $\mathrm{Na}^{+}(\mathrm{A}), \mathrm{Cl}^{-}(\mathrm{B}), \mathrm{K}^{+}(\mathrm{C}), \mathrm{Ca}^{2+}(\mathrm{D})$, and $\mathrm{Mg}^{2+}(E)$. Error bars indicate standard error; $\mathrm{n}=5$; different letters above bars for each organ indicate significant difference $(p \leq 0.05)$. 


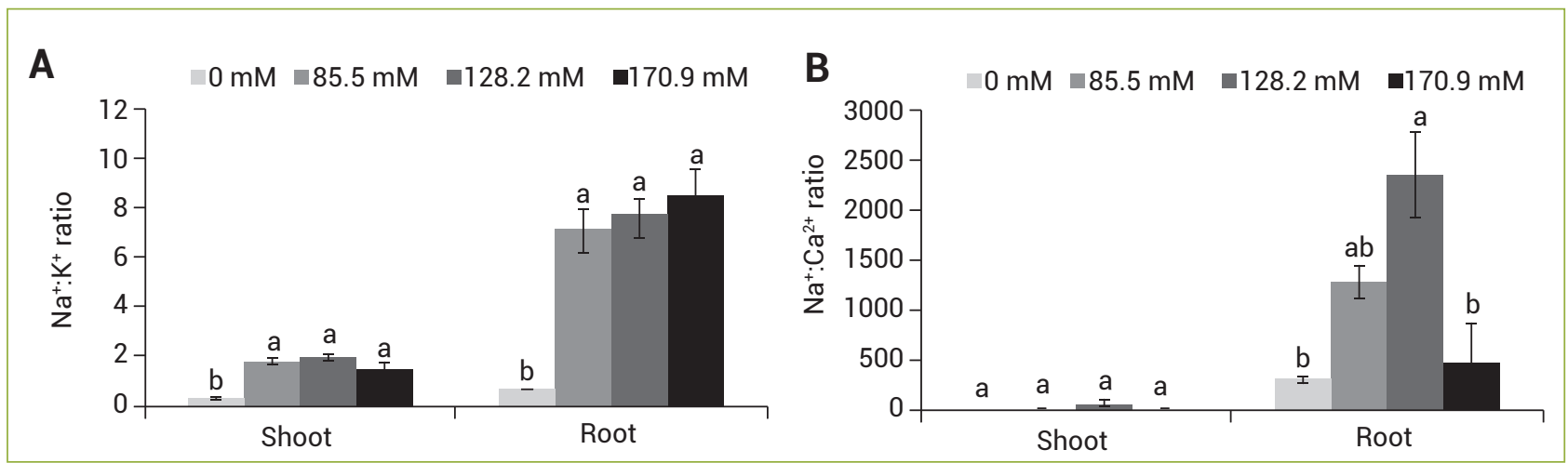

Figure 3. Ion ratios in 7-day-old seedlings of stylo 184 after treatment with $0-170.9 \mathrm{mM} \mathrm{NaCl} . \mathrm{Na}^{+}: \mathrm{K}^{+}(\mathrm{A})$, and $\mathrm{Na}^{+}$: $\mathrm{Ca}^{2+}(\mathrm{B})$. Error bars indicate standard error; $n=3$; different letters above bars for each organ indicate significant difference $(p \leq 0.05)$.

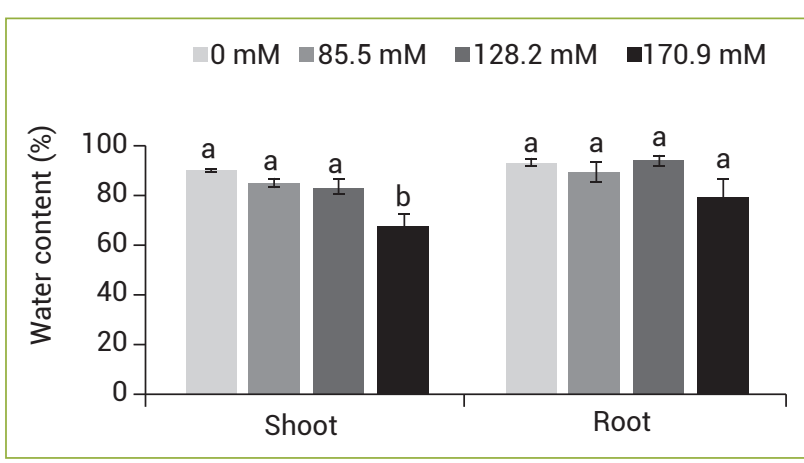

Figure 4. Water content in 7-day-old seedlings of stylo 184 after treatment with $0-170.9 \mathrm{mM} \mathrm{NaCl}$. Error bars indicate standard error; $n=5$; different letters above bars for each organ indicate significant difference $(\mathrm{p} \leq 0.05)$.

levels at all $\mathrm{NaCl}$ concentrations, while $\mathrm{T} 3$ and $\mathrm{T} 4$ decreased $\mathrm{K}^{+}$with increasing $\mathrm{NaCl}$ (Figure $8 \mathrm{C}$ ).

Even though $\mathrm{T} 1$ and $\mathrm{T} 2$ had the same trend in retaining $\mathrm{K}^{+}$content, T2 was also able to maintain $\mathrm{Ca}^{2+}$ and $\mathrm{Mg}^{2+}$. However, in $\mathrm{T} 1, \mathrm{Ca}^{2+}$ was reduced in the salt medium while $\mathrm{Mg}^{2+}$ increased mainly at $170.9 \mathrm{mM} \mathrm{NaCl}$ (Figures 8D, E). T3, T4 and T5 showed strong reduction in $\mathrm{Ca}^{2+}$ content already at $85.5 \mathrm{mM} \mathrm{NaCl}$, whereas only T3 showed decrease in $\mathrm{Mg}^{2+}$ content, which was observed from $170.9 \mathrm{mM} \mathrm{NaCl}$ (Figures 8D, E).

The variable changes in the ion content of clones led to significant differences in the $\mathrm{Na}^{+}: \mathrm{K}^{+}$ratios and the $\mathrm{Na}^{+}: \mathrm{Ca}^{2+}$ ratios. Based on the two-way interaction, as a result of high $\mathrm{K}^{+}$and low $\mathrm{Na}^{+}, \mathrm{T} 1$ had the lowest $\mathrm{Na}^{+}: \mathrm{K}^{+}$ratio. $\mathrm{T} 2$, however, showed the opposite effect with a significantly higher $\mathrm{Na}^{+}: \mathrm{K}^{+}$ ratio than all the other clones (Figure 9A). The other clones had intermediate responses. T5 had no significant differences in the $\mathrm{Na}^{+}: \mathrm{K}^{+}$ratio from 85.5 to $170.9 \mathrm{mM} \mathrm{NaCl}$, while the other clones increased. $\mathrm{T} 3 \mathrm{had}$ the highest $\mathrm{Na}^{+}: \mathrm{Ca}^{2+}$ ratio. Only T2 maintained a stable $\mathrm{Na}^{+}: \mathrm{Ca}^{2+}$ ratio when exposed to $\mathrm{NaCl}$ (Figure 9B).

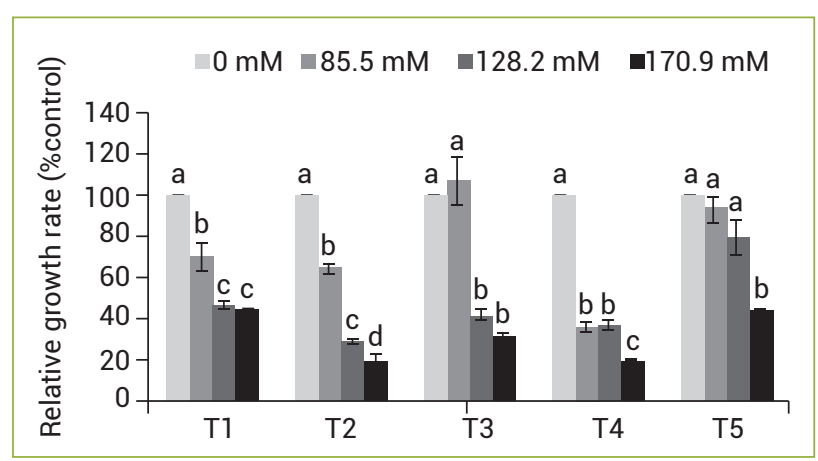

Figure 5.Growth of callus from stylo 184 selected clones after treatment with $0-170.9 \mathrm{mM} \mathrm{NaCl}$ for 15 days. Error bars indicate standard error; $n=10$; different letters above bars for each clone indicate significant difference $(\mathrm{p} \leq 0.05)$. T1, T2, T3, T4 and T5 are selected clones of Stylo 184.

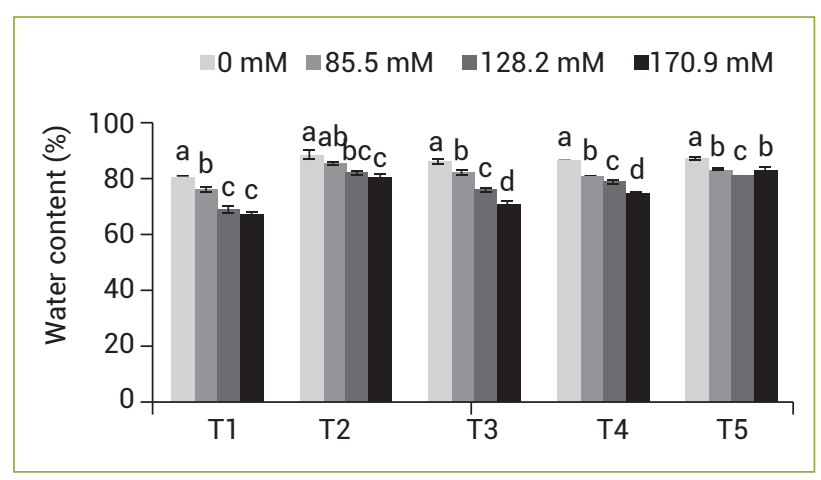

Figure 6. Water content of callus from stylo 184 selected clones after treatment with $0-170.9 \mathrm{mM} \mathrm{NaCl}$ for 15 days. Error bars indicate standard error; $n=10$; different letters above bars for each clone indicate significant difference $(p \leq 0.05)$. T1, T2, T3, T4 and $\mathrm{T} 5$ are selected clones of Stylo 184.

\section{DISCUSSION}

Germination, growth, and ion content in seedling: $\mathrm{NaCl}$ (up to $170.9 \mathrm{mM}$ ) reduced seedling growth, but had no effect on percentage germination, and this result was similar 


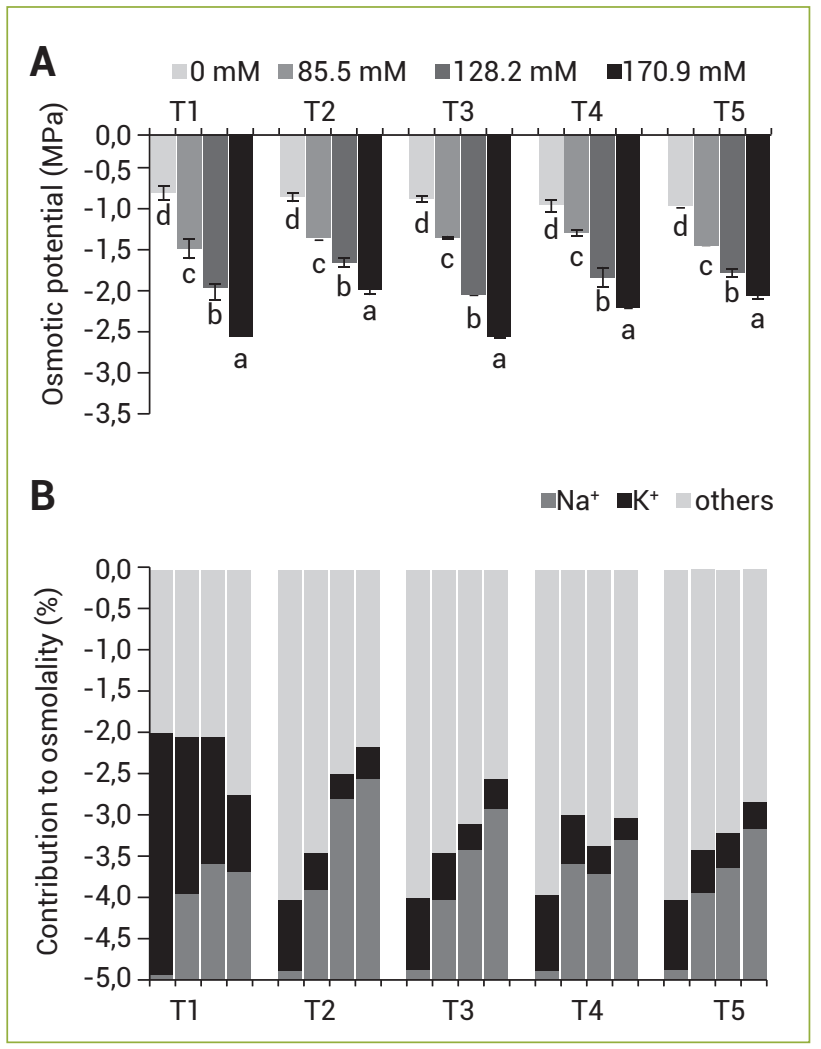

Figure 7.Cell sap determination of callus from stylo 184 selected clones after treatment with $0-170.9 \mathrm{mM} \mathrm{NaCl}$ for 15 days. Osmotic potential (A) and contribution to osmolality by $\mathrm{Na}^{+}$and $\mathrm{K}^{+}(\mathrm{B})$. Error bars indicate standard error; $\mathrm{n}=3$; different letters above bars for each clone indicate significant difference $(p \leq 0.05)$. T1, T2, T3, T4 and T5 are selected clones of Stylo 184.

to that reported for a range of other species (Chartzoulakis and Klapaki 2000, Shannon et al. 2000, Bayuelo-Jimenez et al. 2002). For other legumes, $\mathrm{NaCl}$ of approximately $341.9 \mathrm{mM}$ or more reduced germination and growth, e.g. soybean (Hosseini et al. 2002) and cowpea (Patel et al. 2010). Similarly, our preliminary study showed that concentrations of $\mathrm{NaCl}$ at $256.4 \mathrm{mM}$ had an effect on germination (reduced to $22 \%$ ), and the highest $\mathrm{NaCl}$ concentration in which the seeds were able to germinate was $290.6 \mathrm{mM} \mathrm{NaCl}$ (unpublished result). The significant reduction in water content achieved at $170.9 \mathrm{mM} \mathrm{NaCl}$ can be attributed to osmotic effects caused by the reduced water uptake by the seedlings (Shannon et al. 2000, Bayuelo-Jimenez et al. 2002, Jamil et al. 2007).

The $\mathrm{Na}^{+}$and $\mathrm{Cl}^{-}$contents in the shoots and roots of Stylo 184 seedlings increased when treated with $\mathrm{NaCl}$. The result, again, reflects what has been frequently reported, that is, $\mathrm{Na}^{+}$and $\mathrm{Cl}^{-}$contents are higher with increasing salinity (e.g. Chartzoulakis and Klapaki 2000, Hosseini et al. 2002, Patel et al. 2010). However, it appeared that the $\mathrm{Cl}$ content in shoots and roots was lower in the treatment with $170.9 \mathrm{mM} \mathrm{NaCl}$ than in that with $128.2 \mathrm{mM} \mathrm{NaCl}$, and this may be related to water content. Such a relationship between $\mathrm{Cl}$ and water content was
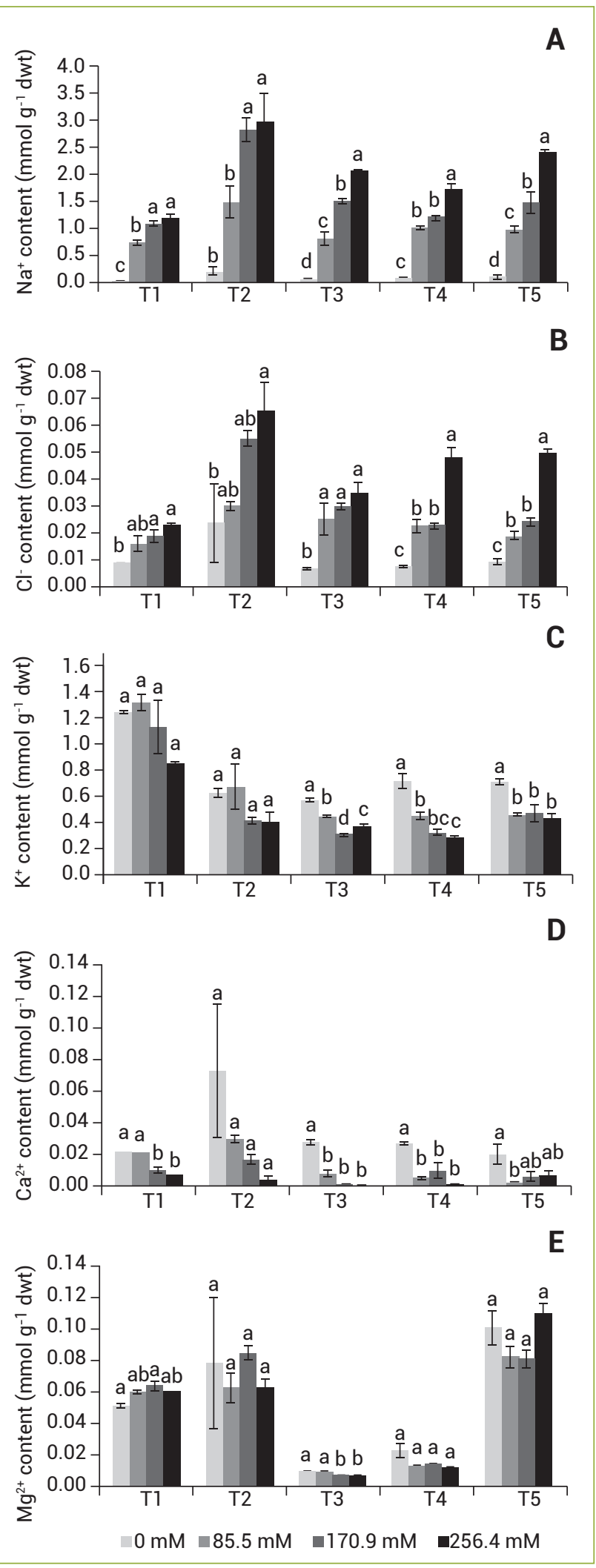

Figure 8. Ion content of callus from stylo 184 selected clones after treatment with 0-170.9 mM NaCl for 15 days. $\mathrm{Na}^{+}(\mathrm{A}), \mathrm{Cl}^{-}(\mathrm{B}), \mathrm{K}^{+}(\mathrm{C}), \mathrm{Ca}^{2+}$ $(\mathrm{D})$, and $(\mathrm{E}) \mathrm{Mg}^{2+}$. Error bars indicate standard error; $\mathrm{n}=3$; different letters above bars for each clone indicate significant difference $(p \leq 0.05)$. T1, T2, T3, T4 and T5 are selected clones of Stylo 184. 


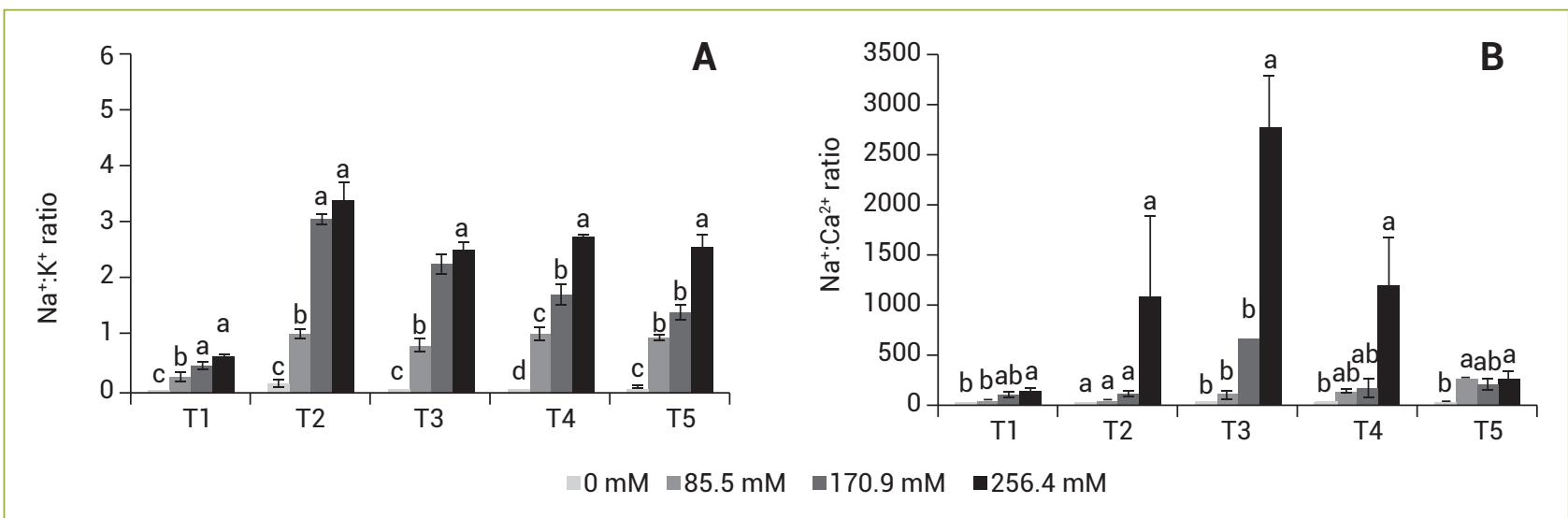

Figure 9. Ion ratios of callus from stylo 184 selected clones after treatment with $0-170.9 \mathrm{mM} \mathrm{NaCl}$ for 15 days. $\mathrm{Na}^{+}: \mathrm{K}^{+}(\mathrm{A})$, and $\mathrm{Na}^{+}: \mathrm{Ca}^{2+}$ (B). Error bars indicate standard error; $n=3$; different letters above bars for each clone indicate significant difference $(p \leq 0.05)$. T1, T2, T3, T4 and T5 are selected clones of Stylo 184.

reported in both sensitive and tolerant clones of Citrus, in which total chloride was highly correlated with total water content (Moya et al. 2003). In addition, stylo 184 was able to prevent the accumulation of toxic ions in the shoots. Lupins (Lupinus luteus and L. angustifolius) also reduce the translocation of both $\mathrm{Na}^{+}$and $\mathrm{Cl}^{-}$to the leaves and stems (Van Steveninck et al. 1982, Teakle et al. 2007), while clover (Trifolium repens; Rogers et al. 1997, Wang et al. 2010) and wild soybean (Glycine soja; Luo et al. 2005) control the translocation of $\mathrm{Cl}^{-}$or $\mathrm{Na}^{+}$to the growing shoots, respectively. This suggests that stylo 184 displayed an exclusion mechanism by accumulating more $\mathrm{Na}^{+}$and $\mathrm{Cl}^{-}$in roots than in shoots.

As a result of salt stress, plants usually face potassium deficiency, as $\mathrm{K}^{+}$uptake is limited by high concentrations of $\mathrm{Na}^{+}$ and xylem translocation is restricted (Patel et al. 2010, Tavakkoli et al. 2010). In Stylo 184, $\mathrm{K}^{+}$content was significantly higher in roots than in shoots, and the total content was 5-7 times lower than the $\mathrm{Na}^{+}$content. This is similar to other legumes, such as cowpea (Vigna anguiculata), faba bean (Vicia faba L.), pea (Pisum sativum L.), soybean (Glycine max L.), and common bean (Phaseolus vulgaris L.) (Cordovilla et al. 1995, Patel et al. 2010). The germination of stylo 184 was stable, possibly due to the preferential $\mathrm{K}^{+}$transport and the reduction of $\mathrm{K}^{+}$translocation to shoots. However, this fact, and perhaps the accumulation of toxic ions, apparently led to reduced seedling growth.

At higher levels of salt (85.5-170.9 mM), stylo 184 was able to maintain both the $\mathrm{K}^{+}$content and the $\mathrm{K}^{+}: \mathrm{Na}^{+}$ratio in both shoots and roots. Plants are able to cope with salt stress by maintaining a high cytoplasmic $\mathrm{K}^{+}: \mathrm{Na}^{+}$ratio (Blumwald 2000, Marcum et al. 2007). As reported in soybean, germination at a higher tissue of $\mathrm{Na}^{+}$concentration in stylo 184 was associated with higher $\mathrm{K}^{+}$and $\mathrm{Ca}^{2+}$ concentrations in the embryo axis (Hosseini et al. 2002). Farhoudi and Sharifzadeh (2006) reported that canola seeds primed with $\mathrm{NaCl}$ subsequently showed high $\mathrm{K}^{+}$and $\mathrm{Ca}^{2+}$ accumulation, including a wellbalanced $\mathrm{Na}^{+}: \mathrm{Ca}^{2+}$ ratio, apparently preventing toxic effects and nutrient deficiency. This type of regulation may have played an important role in osmotic adjustment for stylo 184 seeds, leading to germination in $170.9 \mathrm{mM} \mathrm{NaCl}$.

\section{Growth and ion content in callus of selected clones:}

Examination of callus growth clearly showed different growth rates and an apparent difference in salt tolerance of the five selected clones, as indicated by relative growth rate, ion regulation and osmotic adjustment. It is possible that a combination of these factors will lead to the level of salt tolerance of individual genotypes (Flowers 2004, Zakharin and Panichkin 2009, Zhou and Yu 2009).

In the present results, callus of $\mathrm{T} 1$ (salt-sensitive) displayed the highest $\mathrm{K}^{+}$content and consequently the lowest $\mathrm{Na}^{+}: \mathrm{K}^{+}$ratio. It also contained the highest percentage of $\mathrm{K}^{+}$, contributing to osmolality, with low osmotic potential, resulting in higher mean dry weight of T1 than T2 and T4. This may have been achieved by $\mathrm{T} 1$, which successfully adjusted the osmotic potential by accumulating $\mathrm{K}^{+}$in the cells. This consumes less energy than the production and accumulation of organic osmolytes, and it would be beneficial to its salt adaptation (Zhou and Yu 2009), i.e. a typical glycophytic response.

$\mathrm{T} 2$ was able to stabilize $\mathrm{K}^{+}, \mathrm{Ca}^{2+}$ and $\mathrm{Mg}^{2+}$, but it showed higher $\mathrm{Na}^{+}$and $\mathrm{Cl}^{-}$content with increasing $\mathrm{NaCl}$. Possibly, this clone may have used the $\mathrm{Na}^{+}$and/or $\mathrm{Cl}^{-}$to adjust its osmotic potential. The high osmotic potential with high $\mathrm{Na}^{+}$ and $\mathrm{Cl}^{-}$content, as well as the highest mean water content among all the clones, may be considered as succulence and this physiological mechanism is used to survive under salinity stress (Khan et al. 1999). Great succulence (particularly in 
the whole plant) can be a key characteristic to evaluate the potential of germplasm in selection and breeding programs for improving salt tolerance (Ottow et al. 2005, Lacerda et al. 2006, Gulzar and Khan 2006). This was different from the response obtained from other clones, which had lower water content. The growth of $\mathrm{T} 2$ was also reduced at higher salt levels in comparison to the other clones selected as "tolerant" (T3, T4 and T5). This may be partly due to the excessive toxic ions in the cytoplasm and for losing high energy through the accumulation of these ions in the vacuole.

T5 had the slowest growth amongst all clones, but it showed what appeared to be the highest tolerance to salt in terms of having the lowest growth reduction when exposed to $\mathrm{NaCl}$. The regulation of $\mathrm{K}^{+}, \mathrm{Ca}^{2+}$, and $\mathrm{Mg}^{2+}$ in this clone led to stable $\mathrm{Na}^{+}: \mathrm{K}^{+}$and $\mathrm{Na}^{+}: \mathrm{Ca}^{2+}$ ratios. Marcum et al. (2007) suggested that the high $\mathrm{Na}^{+}: \mathrm{K}^{+}$ratio can disrupt various enzymatic processes in the cytoplasm. Salt-tolerant plants respond to elevated $\mathrm{Na}^{+}$concentrations by maintaining low cytosolic $\mathrm{Na}^{+}$concentrations with high cytosolic $\mathrm{K}^{+}: \mathrm{Na}^{+}$ratios through the extrusion and/or intracellular compartmentalization (Blumwald 2000). For example, callus of Distichlis spicata tolerant genotypes had a higher $\mathrm{K}^{+}: \mathrm{Na}^{+}$ratio than sensitive genotypes (Marcum et al. 2007). Under the current conditions, T5 appears to have better control of $\mathrm{K}^{+}$, and hence was able to maintain growth at higher $\mathrm{NaCl}$ concentrations.

Five clones were selected according to their germination ability under salt stress conditions as a criterion to indicate tolerance. The mechanism used by non-selected seedlings (seven days old) to overcome the secondary effect of salt stress should be related to the clones selected as tolerant. The results presented in this research indicate that exclusion mechanisms play an important role for stylo 184 seedlings to survive under salt stress conditions. The salt sensitive clone (T1) displayed typical responses of glycophytes, including high accumulation of $\mathrm{K}^{+}$and maintenance of low levels of $\mathrm{Na}^{+}$and $\mathrm{Cl}$ (Sairam and Tyagi 2004). This approach eventually leads to the reduced growth or death if the exposure is prolonged or if the salt stress increased (Zakharin and Panichkin 2009). On the other hand, the variation of osmotic adjustment found in the clones selected as tolerant (T2, T3, T4 and T5) revealed salt-resistant glycophyte mechanisms by accumulating, to various degrees, $\mathrm{Na}^{+}$and $\mathrm{Cl}$, as well as $\mathrm{K}^{+}$, as osmolytes. These results indicate that higher preferential $\mathrm{K}^{+}$accumulation can be used as a criterion to discriminate salt-sensitive clones from clones of stylo 184 selected as being tolerant to salt. Understanding these differences may be useful to increase the salt tolerance of this plant for its inclusion in the restoration of salt affected soil as well as its use as a fodder plant.

\section{ACKNOWLEDGEMENTS}

The authors thank the Strategic Scholarships for Frontier Research Network for Ph.D. Programs (V. Veraplakorn) from the Office of the Higher Education Commission, Thailand. Seed material was supplied by the Department of Livestock, Thailand. Comments on the manuscript from Drs. Boyce and Lemson are gratefully acknowledged.

\section{REFERENCES}

Adriano DC, Doner HE (1982) Bromine, chlorine, and fluorine. In: Page AL (ed), Methods of Soil Analysis, pp.449-483. The American Society of Agronomy, Inc. and Soil Science Society of America, USA.

Ahmad MSA, Javed F, Javed S, Alvi AK (2009) Relationship between callus growth and mineral nutrients uptake in saltstressed Indica rice callus. Journal of Plant Nutrition 32:382-394.

Al Sherif EA (2009) Melilotus indicus (L.) All., a salt-tolerant wild leguminous herb with high potential for use as a forage crop in salt-affected soils. Flora 204:737-746.

Amirjani MR (2010) Effect of salinity stress on growth, mineral composition, proline content, antioxidant enzymes of soybean. American Journal of Plant Physiology 5:350-360.

Arulbalachandran D, Ganesh KS, Subramani A (2009) Changes in metabolites and antioxidant enzyme activity of three Vigna species induced by $\mathrm{NaCl}$ stress. American-Eurasian Journal of Agronomy 2:109-116.

Ashraf M, Iram A (2005) Drought stress induced changes in some organic substances in nodules and other plant parts of two potential legumes differing in salt tolerance. Flora 200:535-546.
Ashraf M, Orooj A (2006) Salt stress effect on growth, ion accumulation and seed oil concentration in an arid zone traditional medicinal plant ajwain (Trachyspermum ammi [L.] Sprague. Journal of Arid Environments 64:209-220.

Barker AV, Pilbeam DJ (2007) Handbook of Plant Nutrition. CRC Press.

Bayuelo-Jimenez JS, Craig R, Lynch JP (2002) Salinity tolerance of Phaseolus species during germination and early seedling growth. Crop Science 42:1584-1594.

Bekheet SA, Taha HS, Solliman ME (2006) Salt tolerance in tissue culture of onion (Allium cepa L.). Arab Journal of Biotechnology 9:467-476.

Bell HL, O'Leary JW (2003) Effects of salinity on growth and cation accumulation of Sporobolus virginicus (Poaceae). American Journal of Botany 90:1416-1424.

Betteridge K, Jones RJ (2001) The response of Stylosanthes hamata cv. Verano to applications of sodium and chloride. Tropical Grassland 35:241-245.

Blumwald E (2000) Sodium transport and salt tolerance in plants. Current Opinion in Cell Biology 12:431-434. 
Chartzoulakis K, Klapaki G (2000) Response of two greenhouse pepper hybrids to $\mathrm{NaCl}$ salinity during different growth stages. Scientia Horticulturae 86:247-260.

Cordovilla MP, Ocana A, Ligero F, Lluch C (1995) Salinity effects on growth analysis and nutrient composition in four grain legumesrhizobium symbiosis. Journal of Plant Nutrition 18:1595-1600.

Farhoudi $\mathrm{R}$, Sharifzadeh $\mathrm{F}$ (2006) The effects of $\mathrm{NaCl}$ priming on salt tolerance in canola (Brassica napus L.) seedlings grown under saline conditions. Indian Journal of Crop Science 1:74-78.

Flowers TJ (2004) Improving crop salt tolerance. Journal of Experimental Botany 55:307-319.

Foolad MR (1996) Response to selection for salt tolerance during germination in tomato seed derived from PI 174263. Journal of the American Society for Horticultural Science 121:1006-1011.

Gulzar S, Khan MA (2006) Comparative salt tolerance of perennial grasses. In: Khan MA, Weber DJ (eds.) Ecophysiology of High Salinity Tolerant Plants, pp 239-253. Springer, Netherlands.

Hassan NS, Shaaban LD, Hashem EA, Seleem EE (2004) In vitro selection for water stress tolerant callus line of Helianthus annus $L$. Cv. Myak. International Journal of Agriculture and Biology 6:13-18.

Homma K, Mochizuki A, Watatsu E, Horie T, Shiraiwa T, Supapoj $\mathrm{N}$, Thongthai C (2008) Relay-intercropping of Stylosanthes guianensis in rainfed lowland rice ecosystem in Northeast Thailand. Plant Production Science 11:385-392.

Hosseini MK, Powell AA, Bingham IJ (2002) Comparison of the seed germination and early seedling growth of soybean in saline condition. Seed Science Research 12:165-172.

Jamil M, Lee KB, Jung KY, Lee D B, Han MS, Rha ES (2007) Salt stress inhibits germination and early seedling growth in cabbage (Brassica oleracea capitata L.). Pakistan Journal of Biological Sciences 10:910-941.

Jefferies RA (1996) Evaluation of seedling selection for salinity tolerance in potato (Solanum tuberosum L.). Euphytica 88:207-213.

Kashyap S, Sharma S (2006) In vitro selection of salt tolerant Morus alba and its field performance with bioinoculants. Horticultural Science 33:77-86.

Khan MA, Unger IA, Showalter AM (1999) Effects of salinity on growth, ion content and osmotic relations in Halopyrum mucronatum (L.) Stapf. Journal of Plant Nutrition 22:191-204.

Lacerda CF, Assis Júnior JO, Lemos Filho LCA, de Oliveira TS, Guimarães FVA, Gomes-Filho E, Prisco JT, Bezerra MA (2006) Morpho-physiological responses of cowpea leaves to salt stress. Brazilian Journal of Plant Physiology 18:455-465.

Liu T, Staden JV (2001) Growth rate, water relations and ion accumulation of soybean callus lines differing in salinity tolerance under salinity stress and its subsequent relief. Plant Growth Regulation 34:277-285.

Luo Q, Yu B, Liu Y (2005) Differential sensitivity to chloride and sodium ions in seedlings of Glycine max and $\mathrm{G}$ soja under $\mathrm{NaCl}$ stress. Journal of Plant Physiology 162:1003-1012.
Marcum KB, Yensen NP, Leake JE (2007) Genotypic variation in salinity tolerance of Distichlis spicata turf ecotypes. Australian Journal of Experimental Agriculture 47:1506-1511.

Mostafazadeh-Fard B, Heidarpour M, Aghakhani A, Feizi M (2007) Effects of irrigation water salinity and leaching on soil chemical properties in an arid region. International Journal of Agriculture and Biology 3:466-469.

Moya JL, Gómez-Cadenas A, Primo-Millo E, Talon M (2003) Chloride absorption in salt-sensitive Carrizo citrange and salttolerant Cleopatra mandarin citrus rootstocks is linked to water use. Journal of Experimental Botany 54:825-833.

Munns R (2002) Comparative physiology of salt and water stress. Plant Cell and Environment 25:239-250.

Murashige T, Skoog F (1962) A revised medium for rapid growth and bioassay with tobacco tissue cultures. Physiologia Plantarum 15:473-497.

Ottow EA, Brinker M, Teichmann T, Fritz E, Kaiser W, Brosché M, Kangasjärvi J, Jiang X, Polle A (2005) Populus euphratica displays apoplastic sodium accumulation, osmotic adjustment by decreases in calcium and soluble carbohydrates and develops leaf succulence under salt stress. Plant Physiology 139:1762-1772.

Patel PR, SS Kajal, Patel VR, Patel VJ, Khristi SM (2010) Impact of salt stress on nutrient uptake and growth of cowpea. Brazilian Journal of Plant Physiology 22:43-48.

Phengsavanh P, Ledin I (2003) Effect of stylo 184 (Stylosanthes guianensis CIAT 184) and Gamba grass (Andropogon gayanus cv. Kent) in diets for growing goats. Livestock Research for Rural Development 15:1-9.

Rogers ME, Noble CL, Halloran GM, Nicolas ME (1997) Selecting for salt tolerance in white clover (Trifolium repens): Chloride ion exclusion and its heritability. New Phytologist 135:645-654.

Ruiz D, Martínez V, Cerdá A (1997) Citrus response to salinity: growth and nutrient uptake. Tree Physiology 17:141-150.

Saha P, Chatterjee P, Biswas AK (2010) $\mathrm{NaCl}$ pretreatment alleviates salt stress by enhancement of antioxidant defense system and osmolyte accumulation in mungbean (Vigna radiata L. Wilczek). Indian Journal of Experimental Biology 48:593-600.

Sairam, RK, Tyagi A (2004) Physiology and molecular biology of salinity stress tolerance in plants. Current Science 86:407-421.

Shannon MC, Grieve CM, Lesch SM, Draper JH (2000) Analysis of salt tolerance in nine leafy vegetables irrigated with saline drainage water. Journal of the American Society for Horticultural Science 125:658-664.

Sidari M, Santonoceto C, Anastasi U, Preiti G, Muscolo A (2008) Variations in four genotypes of lentil under $\mathrm{NaCl}$-salinity stress. American Journal of Agricultural and Biological Sciences 3:410-416

Tavakkoli E, Rengasamy P, McDonald GK (2010) High concentrations of $\mathrm{Na}^{+}$and $\mathrm{Cl}^{-}$ions in soil solution have simultaneous detrimental effects on growth of faba bean under salinity stress. Journal of Experimental Botany 61:4449-4459. 
Teakle NL, Flowers TJ, Real D, Colmer TD (2007) Lotus tenuis tolerates the interactive effects of salinity and water logging by 'excluding' $\mathrm{Na}^{+}$and $\mathrm{Cl}^{-}$from the xylem. Journal of Experimental Botany 58:2169-2180.

Tejera NA, Soussi A, Lluch C (2006) Physiology and nutritional indicators of tolerance to salinity in chickpea plants growing under symbiotic conditions. Environmental and Experimental Botany 58:17-24.

Ueda A, Kanechi M, Uno Y, Inagaki N (2003) Photosynthetic limitations of a halophyte sea aster (Aster tripolium L.) under water stress and $\mathrm{NaCl}$ stress. Journal of Plant Research 116:65-70.

Van Steveninck RFM, Van Steveninck ME, Stelzer R, Läuchli A (1982) Study on the distribution of $\mathrm{Na}$ and $\mathrm{Cl}$ in two species of lupin (Lupinus luteus and Lupinus angustifolius) differing in salt tolerance. Physiologia Plantarum 56:465-473.

Veraplakorn V, Na Nakorn M, Kaveeta L, Srisom Suwanwong S, Bennett IJ (2012) Variation and long term regenerative capacity of two important tropical forage legumes: Cavalcade (Centrosema pascuorum cv. Cavalcade) and Stylo 184 (Stylosanthes guianensis CIAT184) in vitro. African Journal of Biotechnology 11:15843-15851.

Wang J, Drayton MC, George J, Cogan NOI, Baillie RC, Hand ML., Kearney GA, Erb S, Wilkinson T, Bannan NR, Forster JW, Smith KF
(2010) Identification of genetic factors influencing salts tress tolerance in white clover (Trifolium repens L.) by QTL analysis. Theoretical and Applied Genetics 120:607-619.

Woodward AJ, Bennett IJ (2005) The effect of salt stress and abscisic acid on proline production, chlorophyll content and growth of in vitro propagation shoots Eucalyptus camaldulensis. Plant Cell Tissue and Organ Culture 82:189-200.

Yacoubi HE, Ayolie K, Rochdi A (2010) In vitro cellular salt tolerance of Troyer citrange: changes in growth and solutes accumulation in callus tissue. International Journal of Agricultural Biology 12:187-193.

Yasumoto E, Adachi K, Kato M, Sano H, Sasamoto H, Baba S, Ashihara H (1999) Uptake of inorganic ions and compatible solutes in cultured mangrove cells during salt stress. In Vitro Cellular and Developmental Biology Plant 35:82-85.

Yokoi S, Bressan RA, Hasegawa PM (2002) Salt stress tolerance of plants. JIRCAS Working Report, pp. 25-33.

Zakharin AA, Panichkin LA (2009) Glycophyte salt resistance. Russian Journal of Plant Physiology 56:107-116.

Zhou Q, Yu BJ (2009) Accumulation of inorganic and organic osmolytes and their role in osmotic adjustment in $\mathrm{NaCl}$-stressed vetiver grass seedlings. Russian Journal of Plant Physiology 56:678-685. 